\title{
上，中位腰椎神経根症の臨床的検討
}

\begin{tabular}{|c|c|c|c|c|}
\hline 橋 & 口 & 隆·弓 & 削 & 大四郎 \\
\hline 三 & 村 & 寛·田 & 口 & 敏 彦 \\
\hline 渡 & 邊 & 精一郎·鈴 & 木 & 暢 彦 \\
\hline 大 & 塚 & 健 & & \\
\hline
\end{tabular}

\section{Clinical Evalation of Upper and Middle Lumbar Radiculopathy}

by

Takashi Hashiguchi, Daishirou Yuge, Hiroshi Mimura, Toshihiko Taguchi, Seiichirou Watanabe, Akihiko Suzuki and Ken Otsuka

Division Orthopaedics of Yamaguchi

Prefectural Central Hospital

We report the clinical evaluation of upper and middle lumbar radiculopathy. Subjects comprised 6 male patients ranging in age from 48-75 years old with a mean of 62 years. The level of the radiculopathy was L1; 1 case, L $2 ; 1$ case, L $3 ; 2$ cases, L 4; 2 cases. Clinically, almost patients complained of lumbago and, thigh or knee pain. Nerve root infiltration was most useful for diagnosis of the level.

Two patients had partial laminectomy and 4 patients had osteoplastic laminectomy. Origin of the radiculopathy were disc herniation (sequestration type); 4 cases, OFL; 1 case, pedicular kinking; 1 case, disc herniation + facet; 1 case. The average length of follow-up was and the mean 19 months improvement rate according to the JOA-score was $68 \%$.

Anatomically, lumbar nerve roots of $\mathrm{L} 1,2,3,4$ emerged lower to disc level compared with L5, S1 roots. Therefore, upper and middle lumbar nerve root radiculopathy is due to a variety of causes. We recommend osteoplastic laminectomy for treatment of upper and middle lumbar radiculopathies.

Key words : lumbar vertebrae (腰椎), laminectomy（椎弓切除), spinal nerve roots (脊䯣 神経根)

\section{目 \\ 的}

上, 中位腰椎レベルの病変は, 馬尾症状を呈する事 が多く神経根症は極めて少ない.また神経根症状を呈 してもいわゆる下肢痛が認められない為, 腰部の局所 症状として捉えられ神経根症と診断されにくい. 今回 は当科で経験した上, 中位腰椎神経根症について臨床 的検討を行ったので報告する。

\section{対象と方 法}

対象は 1990 年 5 月から 1993 年 6 月までに手術を行っ た腰椎神経根症 118 例中の 6 例である。手術時年齢は 48 から 75 歳, 平均 62 歳, 追跡期間は 6 力月から 2 年 10 力月, 平均 1 年 7 力月であった。 以上の症例に ついて臨床症状, 理学所見, 診断, 手術方法, 治療成 績を調查した. 
結

果

羅患神経根は L1 神経根 : 1 例, L2 : 1 例, L $3: 2$ 例, L4 : 2 例であった. 臨床症状は全例腰痛を認め, 加えて L1，2 では大腿部痛，L3，4では膝痛を訴え， 腰痛よりも下肢症状が強かった。

理学所見は SLR 陽性 2 例, FNST 陽性 4 例, 膝蓋 腱反射低下 5 例，筋力低下は腸腰筋 1 例，大腿四頭筋 3 例，知覚低下は L1 が大腿全面，L3 は膝内側， L4 に下腿内側であった（表 1 ).

診断には脊髄造影，CTM，MRIを行ったが，これ らでは他にも圧迫病変を示す部位が発見されたりする ことがある. 責任神経根の確定には神経根ブロックが 最も有用であった。

術式は L3，4 のそれぞれ 1 例に部分椎弓切除術を 行い, 他は全て骨形成的椎弓切除術を行った。 術中所 見での圧迫因子は遊離脱出したヘルニア 4 例, 黄色勒 帯骨化 1 例, 椎弓根 1 例, ヘルニアと椎間関節 1 例で あった，治療成績は日整会判定基準に従い術前平均 10 点, 退院時 19 点, 追跡調查時 23 点と改善してい た.

\section{症 例 供 覧}

57 歳, 男性. 誘因無く腰痛, 右膝内側部痛出現し た. 理学所見はSLR： $60^{\circ}$, FNST：陰性, 右膝蓋 腱反射低下, 知覚低下無し. 右腸腰筋と大腿四頭筋は 筋力低下がみられた，脊髄造影で右 L3 神経根欠損像 を認め, 神経根ブロックで一時的な疼痛消失を見た (図 1). L2 椎弓の骨形成的偏側椎弓切除術を行い L3 椎体レベルまでたれさがった遊離脱出したヘルニア塊
を摘出した，術後 10 日間の安静臥床後, 軟性コルセッ トで歩行開始し 4 カ月間装着した。 JOA score は術 前 4 点から 6 カ月後 22 点に改善していた.

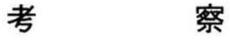

上, 中位腰椎神経根症の報告は少なく, 頻度も我々 の症例では同時期に行った腰椎神経根症 118 例中 6 例 5 \%と少なかった．これは上，中位腰椎神経根は L5 根に対する $\mathrm{L} 4 / 5, \mathrm{~S} 1$ 根に対する $5 / \mathrm{S}$ と比較して, 神 経根分岐部が椎間板レベルより下方にあり，通常のへ ルニアなどでは馬尾症状となり，神経根症をきたしに 〈いためと考えられる11314)9). 当科で行った下位腰椎 椎間板ヘルニア症状 (40 例) のCTM で各椎間板レベ ルの神経根像描出の有無を見ると，L1/2，2/3，3/4
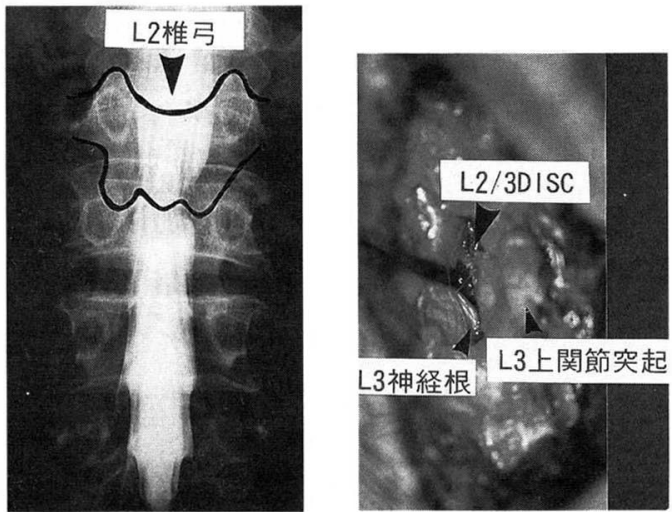

図 157 歳. 男性. 脊髄造影では L3 神経根の欠損像 を認め，L2/3の椎弓間より上方にある. L2 の 骨形成的偏側椎弓切除術を行い, L2/3 よりの 遊離脱出したヘルニアを摘出した。

表 1 理学所見

\begin{tabular}{|c|c|c|c|c|c|c|c|}
\hline \multirow[b]{2}{*}{ 症例 } & \multirow[b]{2}{*}{ レベル } & \multirow[b]{2}{*}{ K.J. } & \multicolumn{3}{|c|}{ 神経脱落症状 } & \multicolumn{2}{|c|}{ 神経根緊張症状 } \\
\hline & & & A.J. & 筋力低下 & 知覚障害 & SLR & FNST \\
\hline 1 & L1 & $\downarrow$ & $\mathrm{N}$ & llio. & 左大腿前面 & $90^{\circ}$ & + \\
\hline 2 & L2 & $\mathrm{N}$ & $\mathrm{N}$ & $\mathrm{N}$ & $\mathrm{N}$ & $90^{\circ}$ & - \\
\hline 3 & L3 & $\downarrow$ & $\mathrm{N}$ & Quad. & $\mathrm{N}$ & $60^{\circ}$ & + \\
\hline 4 & L3 & $\downarrow$ & $\mathrm{N}$ & Quad. & $\begin{array}{c}\text { 右大腿 } \\
\text { 膝内側 }\end{array}$ & $90^{\circ}$ & - \\
\hline 5 & L4 & $\downarrow$ & $\mathrm{N}$ & $\mathrm{N}$ & $\begin{array}{l}\text { 右大腿 } \\
\text { 下腿内側 }\end{array}$ & $60^{\circ}$ & + \\
\hline 6 & L4 & $\downarrow$ & $\downarrow$ & Quad. & $\begin{array}{l}\text { 左膝 } \\
\text { 下腿内側 }\end{array}$ & $80^{\circ}$ & + \\
\hline
\end{tabular}




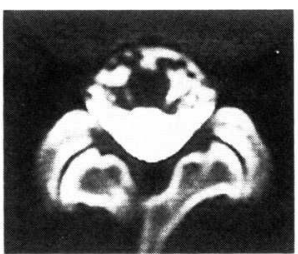

L1/2

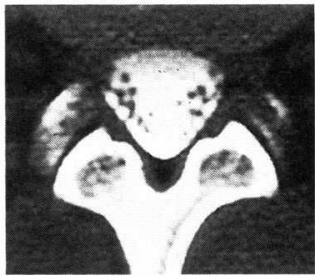

L3/4

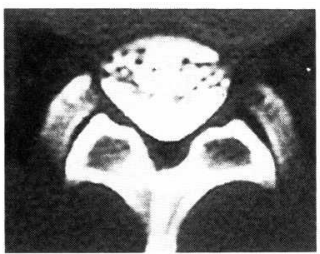

L2/3

\begin{tabular}{cccc}
\hline \hline & 描出なし & 根瞿部のみ & 神経根描出 \\
\hline $\mathrm{L} 1 / 2$ & 0 例 & 0 & 40 \\
$\mathrm{~L} 2 / 3$ & 0 & 1 & 39 \\
$\mathrm{~L} 3 / 4$ & 0 & 9 & 31 \\
$\mathrm{~L} 4 / 5$ & 1 & 20 & 19 \\
$\mathrm{~L} 5 / \mathrm{S}$ & 23 & 14 & 3 \\
\hline
\end{tabular}

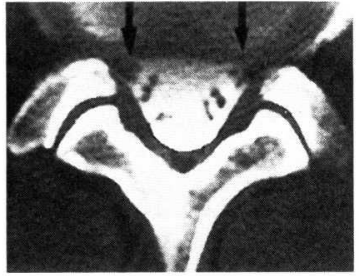

L4/5

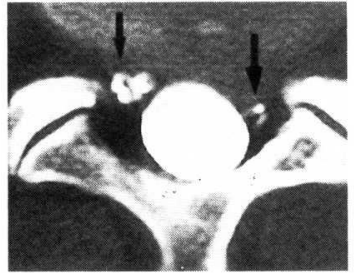

L5/S

図 2 下位腰椎ヘルニア 40 例の CTM で椎間板レベルの神経根描出の有無を見ると, L1 $/ 2,2 / 3 ， 3 / 4$ では明らかに神経根が描出されたものは無く, L4/5 では根䧶部の突 出のみが多く, L5/Sでは神経根が良く描出されていた.

レベルでは明らかに神経根が描出されたものは無く， L4/5 では根囊部の突出のみが多く, L5/S では神経 根が良く描出されていた $(\text { 図 2 })^{2) 8)}$. 従って上, 中位 腰椎レベルで神経根症を来す場合, 今回の症例のよう に多彩な圧迫因子が考えられ, 神経根が分岐部から神 経孔部まで確認できる骨形成的椎弓切除術が有効な術 式と考えられる ${ }^{10)}$.

本症の臨床的特徴は, 同時期に行った下位腰椎神経 根症平均 46 歳と比較して, 平均 62 歳と高齢であり, 臨床症状は腰痛に大腿部, 膝部の疼痛を主訴とするも のが多かった.このことより腰の局所症状に変形性関 節症を合併したものと鑑別に留意すべきと考えられ $た^{5(6) 7) 12)}$. 診断は画像上他部位に硬膜管の圧迫を見る ことも多く，責任神経根レベルの診断には神経根ブロッ クが有用であった.

$$
\text { ま と め }
$$

(1)上, 中位腰椎神経根症 6 例の臨床的検討を行った. (2)治療成績は術前 JOA 平均 10 点から調査時 23 点に 改善していた.

(3)上, 中位腰椎は下位腰椎と比較して, 神経根分岐部 が椎間板レベルより下方にあるため多彩な圧迫因子が 考えられ, 神経根が分岐部から椎間孔部まで確認でき
る骨形成的椎弓切除術が有効な術式と考えられた.

\section{参 考 文 献}

1）有田親史：上位椎間板ヘルニアについて. 中部整災誌, 24 : 263-264, 1981.

2) ERIC J. WALL: Original of Intrathecal Nerve Roots at the Level of the Conus Medullaris.J.Bone Joint Surg., 72-A : 1495-1499, 1990.

3）藤村祥一：上位腰椎椎間板ヘルニアの臨床像. 日整会 誌, $57: 1462-1463,1983$.

4）林 春樹：上位椎間板ヘルニアの臨床的検討. 関東整 災誌, $14:$ 159-163, 1983.

5）栗原 章 : 腰部神経根症状を伴った変形性膝関節症の 検討. 中部整災誌, $32: 1886-1887,1989$.

6）黒坂昌弘: 変形性膝関節症と腰痛. 関節外科, 9:215$220,1990$.

7）久野木順一：腰部神経根症に伴う膝部痛の検討. 臨整 外, $28: 709-717,1993$.

8) MARK S. COHEN: THE ANATOMY OF THE CAUDA ON CT SCANS AND MRI. J. Bone Joint Surg., 73-B : 381-384, 1991.

9）大島 博 : 上位腰椎椎間板ヘルニアの臨床症状, 局所 病態と治療. 中部整災誌, $35: 571-572,1992$.

10）田口敏彦 : Extraforaminal lumbar disc herniation の最近の自験例について. 整形外科と災害外科, 38 : 125-128, 1989.

11）寒辻雅章 : 腰部神経根症状を伴った変形性膝関節症の 検討. 日整会誌, $64: S 629,1990$. 